\title{
Mass removal efficiencies in water and consequences after a river diversion into coastal wetlands: second thoughts
}

\author{
R. Eugene Turner ${ }^{(D)} \cdot$ Erick M. Swenson $\cdot$ \\ James M. Lee $\cdot$ Charles S. Milan
}

Received: 9 June 2021 / Revised: 19 October 2021 / Accepted: 21 November 2021

(C) The Author(s) 2022

\begin{abstract}
Salinity control, nutrient additions, and sediment supply were directly or indirectly the rationale for a \$220 million coastal wetland restoration project (Davis Pond River Diversion) that began in 2002. We sampled Mississippi River water going in and out of the receiving basin from 1999 to 2018 to understand why wetland loss increased after it began. There was a reduction in inorganic sediments, nitrogen $(\mathrm{N})$, and phosphorus $(\mathrm{P})$ concentrations within the ponding area of $77 \%, 39 \%$ and $34 \%$, respectively, which is similar to that in other wetlands. But the average sediment accumulation of $0.6 \mathrm{~mm}$ year $^{-1}$ inadequately balances the present-day $5.6 \mathrm{~mm}$ year $^{-1}$ sea level rise or the $7.9 \pm 0.13 \mathrm{~mm}$ year $^{-1}$ accretion rates in these organic soils. Nutrients added likely reduced live belowground biomass and soil strength, and increased decomposition of the organic matter necessary to sustain elevations. The eutrophication of the downstream aquatic system from the diversion, principally by $\mathrm{P}$
\end{abstract}

Guest editors: Andre A. Padial, Dennis F. Whigham, Ken W. Kraus \& Emily M. Dangremond / Emerging Studies in Aquatic Sciences - an Homage to Dr. Brij Gopal's Legacy

Supplementary Information The online version contains supplementary material available at https://doi. org/10.1007/s10750-021-04770-z.

R. E. Turner $(\bowtie) \cdot$ E. M. Swenson · J. M. Lee ·

C. S. Milan

Department of Oceanography and Coastal Sciences, Louisiana State University, Baton Rouge, LA 70803, USA

e-mail: euturne@1su.edu additions, increased Chl $a$ concentrations to a category of 'poor' water quality. We conclude that this diversion, if continued, will be a negative influence on wetland area and will eutrophy the estuary. It is a case history example for understanding the potential effects arising from proposed river diversions.

Keywords Nutrient removal - Wetland gain and loss $\cdot$ Restoration $\cdot$ River diversion $\cdot$ Eutrophication

\section{Introduction}

Humans have changed coastal landscapes as they moved some or all of a river's flow across landscapes throughout human histories for a variety of reasons. The dikes of the Yellow River, for example, were breached in $1128 \mathrm{CE}$ for military reasons, and the resulting river avulsion captured the nearby Huai river, which later became blocked; the Yellow river soon debouched to the south of the Shandong Peninsula and into the Yellow Sea. Agricultural expansion in England's Wash began in the late 1500's and led to re-direction of numerous river flows (Ash, 2017). The Venetians diverted the Po River in 1604-1607 by builting the $5 \mathrm{~km}$ long Taglio di Po canal going from the Venice lagoon to a southeastern lagoon, reducing sediment loading in one while gaining in the other. The Everglades ecosystem is riddled with water re-direction around, into and out of wetlands that have changed under various political pressures 
(Gunderson \& Light, 2006). Eighty-eight percent of the Santee River (Charleston, SC) was redirected into the Cooper River in 1941 to develop hydroelectricity, only to have part of it redirected back by 1975 because of shoaling in Charleston Harbor (Bradley et al., 1990).

Other river diversions done for a different purpose are the ongoing and planned partial diversions of the Mississippi River into the adjacent coastal wetlands. Louisiana, at the time of planning and construction for the first diversion of the Mississippi River water into freshwater wetlands, had dramatically high land losses (54 km² year ${ }^{-1}$ from 1956 to 2010) which became a small gain from 2010 to 2016 (Couvillon et al., 2017). These losses continue to be the rationale for wetland restoration efforts today. The narrowly authorized administrative purpose of the Davis Pond Diversion was to control salinity in the estuary; but the general expectation in various reports, brochures, and science articles was that the "Introduction of fresh water, nutrients and sediments from the Mississippi River via the Davis Pond Freshwater Diversion structure will serve to reduce this land-loss and ecosystem degeneration trend in the Barataria Basin" (Plitsch, 2018). There was an unsupported conclusion that wetland forests were nutrient limited belowground (Schaffer et al., 2016) when it was known that with flooding was a stressor (Megonigal et al., 1977). The assumptions were that adding sediments, reducing and controlling salinity would enhance plant production above and belowground. The anticipated consequences of the Davis Pond river diversion were estimated to preserve $133.5 \mathrm{~km}^{2}$ of wetlands and benefit $3,144 \mathrm{~km}^{2}$ of marshes and bays during the 50 -year life of the project (CPRA, 2020). The entire Barataria watershed is $6,600 \mathrm{~km}^{2}$, indicating that this one restoration effort was supposed to benefit $48 \%$ of the Barataria watershed. Perhaps this conclusion was an administrative overreach, but the diversion was also funded with the assumption that sediments that used to flow over the levees to build land were lost when they flowed offshore beyond the delta. It has since been well-documented that most of these sediments are largely retained within the river delta to maintain the main channel and adjacent wetlands (Allison et al., 2012; Turner, 2017). Furthermore, only about $2 \%$ of the Mississippi River sediments went over the natural levees before construction of flood protection levees (Kesel, 1989). The vertical growth of modern marshes inland of the modern delta tip is not comprised inorganic sediments, but mostly of water, air and organic matter, making the balance of organics an important focal point.

Wetland restoration of the area receiving the diverted water did not happen-instead, wetland loss increased (Turner et al., 2019a; Supplemental Fig. S1). Why wetland loss rates increased after the diversion was opened is one focus of this paper. A second focus is to address the omission noted by Land et al. (2016) who highlighted the lack of long-term data on the nutrient removal rates of wetlands. Here we provide results based on monthly water quality measurements made from 1999 to 2016 (17 years) in water entering and leaving the receiving basin.

\section{Methods}

The Davis Pond Diversion structure and water flow

The study area is where Mississippi River water is diverted into and out of a leveed receiving basin in southern Louisiana. The Davis Pond freshwater diversion structure is located on the right side of the downstream bank of the Mississippi River, $192 \mathrm{~km}$ above head-of-passes at the tip of the Mississippi River Delta and $8 \mathrm{~km}$ upstream from New Orleans. The Davis Pond structure consists of four $4.3 \mathrm{~m}$ square gated box culverts feeding a pumping station that primes a gravity driven discharge of up to $300 \mathrm{~m}^{3} \mathrm{~s}^{-1}$ of Mississippi River water (Swenson et al., 2006). This water goes into a $3.4 \mathrm{~km}$ long by $37 \mathrm{~m}^{2}$ wide conveyance channel that enters a 3,768 ha ponding area bounded on all sides by $30.6 \mathrm{~km}$ of levees. The ponding area receives about $2.46 \mathrm{~m}$ of rainfall annually, equivalent to $6 \%$ of the average amount of Mississippi River entering the pond. The holding pond has a mixture of fresh marsh and swamp vegetation. The water then exits the ponding area through openings in the $2.9 \mathrm{~km}$ of rock weir and enters the $1.8 \mathrm{~m}$ deep and 3,678 ha Lake Cataouatche ('Cata' means 'lake' in the Choctaw language and 'Ouache' is the tribal name), located in the northern portion of the Barataria watershed (Fig. 1; www.mvn.usace.army. mil/About/Projects/Davis-Pond-Freshwater-Diver sion/.pdf). Water then exits through the two passes on either side of Couba Island, and into the northeastern portion of Lake Salvador. Water from Bayou des 


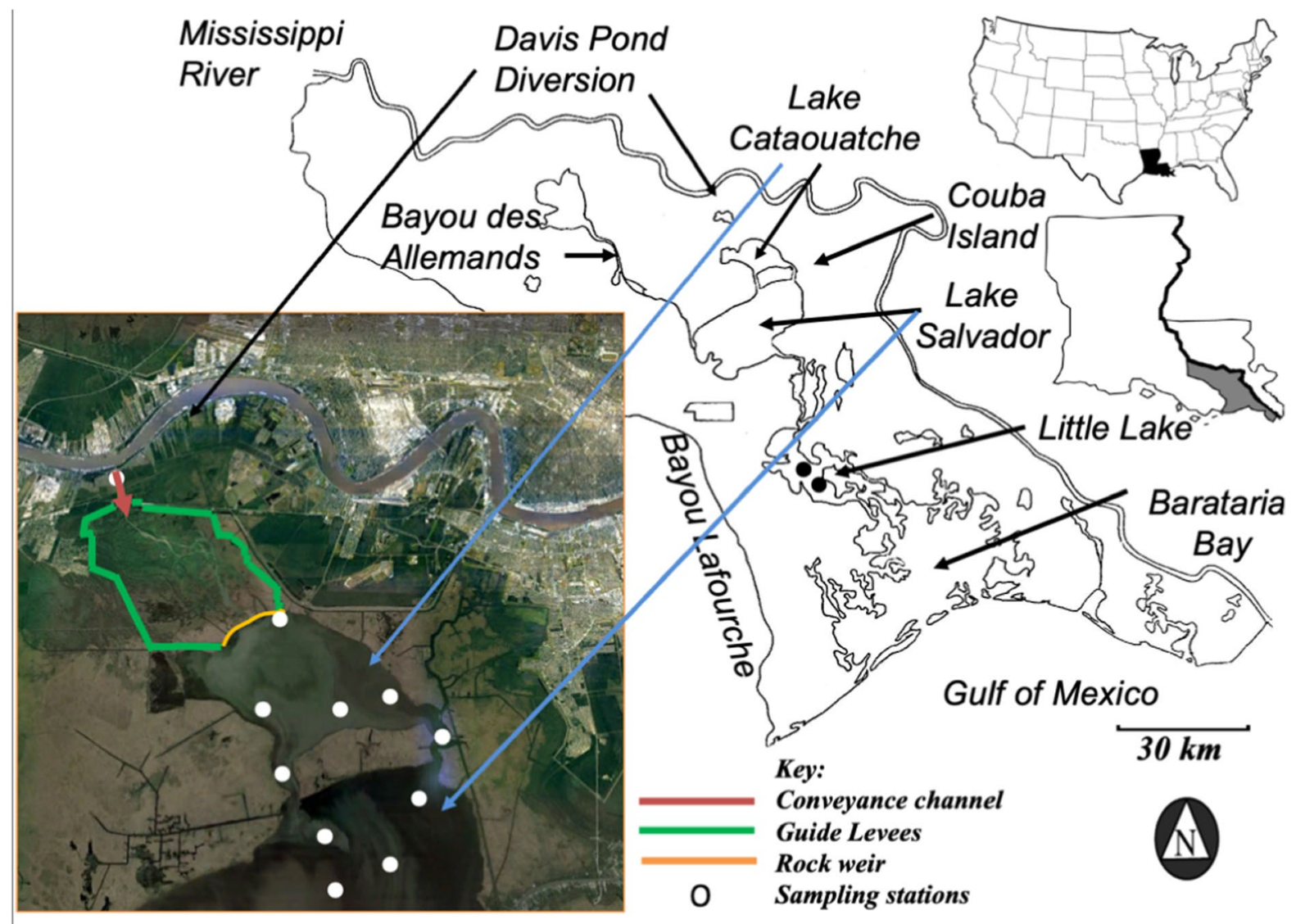

Fig. 1 The location and design of the Davis Pond diversion of Mississippi River water into wetlands of the Barataria watershed. Water flows from a conveyance channel into a ponding area constrained by guide levees and into Lake Cataouche. It then leaves on either side of Couba Island and into Lake Sal-

Allemands enters at the western end of $1.8 \mathrm{~m}$ deep Lake Salvador and enters Bayou Perot to mix with the westward moving water from the Intracoastal Waterway that seasonally peaks with spring floods (Swarzenski, 2003). Water then enters Little Lake that had an average salinity from 1994 to 2016 of 1.81 $(\mathrm{SEM} \pm 0.15)$ (Turner et al., 2019b), before becoming saltier as it mixes with the Gulf of Mexico within the Barataria Bay estuary further south. The $30-\mathrm{cm}$ tidal range in Barataria Bay is dominated by meteorological rather than astronomical drivers that distinguishes the Gulf of Mexico (GOM) estuaries from other coastal US estuaries (Turner, 2001). Tidal influences are further diminished in the Lake Salvador area and northward and are $0.3 \mathrm{~m}$ in Lake Cataouatche. vador, to Little Lake, and then to Barataria Bay. The colored inset depicts the sampling station locations (white dots) where water samples were taken. Two other stations are in Little Lake (black dots)

There are two possible sources of water that might dilute water in Lake Cataouatche if concentrations are low enough: (1) rainfall and (2) water from Lake Salvador as it mixes with Lake Cataouatche through the Couba Island passes. The annual rainfall volume is about $6 \%$ of the total water volume coming from the diversion, so rainfall is not a meaningful diluent. The Lake Cataouatche volume is turned over every 17 days by water coming in through the diversion, on average, for an equivalent volume of 6\%. Das (2010) estimated that the daily tidal prism was $1.9 \times 10^{6}$ $\mathrm{m}^{3}$ compared to $130 \times 10^{6} \mathrm{~m}^{3}$ for Lake Cataouatche and surrounding wetlands, and a tidal exchange of $5.1 \times 10^{6} \mathrm{~m}^{3}$ and $520 \times 10^{6} \mathrm{~m}^{3}$ in Lake Salvador. The daily tidal flushing exchanges for Lakes Cataoutache 
and Salvador are, therefore, $1.5 \%$ and $1 \%$, respectively, and much lower than the flushing from the diversion water. As will be shown below, the water in the immediate vicinity of Couba Island is of nearly identical concentrations as in Lake Cataoucatche. The concentrations in rainfall, of course, are much lower. We conclude that mixing of water and its constituents in Lake Cataoutche is dominated by inflow from the diversion, not from mixing with rainfall or by water in Lake Salvador.

The project was authorized by the Flood Control Act of 1928, (PL 70-391) and the Flood Control Act of 1965, (PL 89-298) and further amended by the Water Resources Development Acts (WDRA) of 1986 (PL 99-622). The initial construction of 8 major contracting elements began in November 1996 and ended in February 2002. The diversion was officially opened for the first time on 26 March 2002. The initial $\$ 120$ million cost for these structures increased by an estimated $\$ 100$ million in 2006 (Brown, 2006) to repair damages resulting from floating vegetation that accumulated upstream of the weirs. Other adjustments included adding more gates before the culverts and five more kilometers of levees and making nine new openings in the rock weir. There is no published monitoring of the area for vegetation composition in the ponding area for before or after the diversion opened that we know of.

\section{Sampling}

We collected water samples from August 1999 through December 2016 for a total of 267 trips to: (1) one station from a bridge that crosses east-to-west over the northern end of the conveyance channel, (2) four stations in Lake Cataouatche, (3) one station each in the eastern and western channels of Couba Island where water leaves Lake Cataouatche, and (4) four stations in Lake Salvador (Figs. 1, 2). Two other stations were sampled in Little Lake (Fig. 1). Water

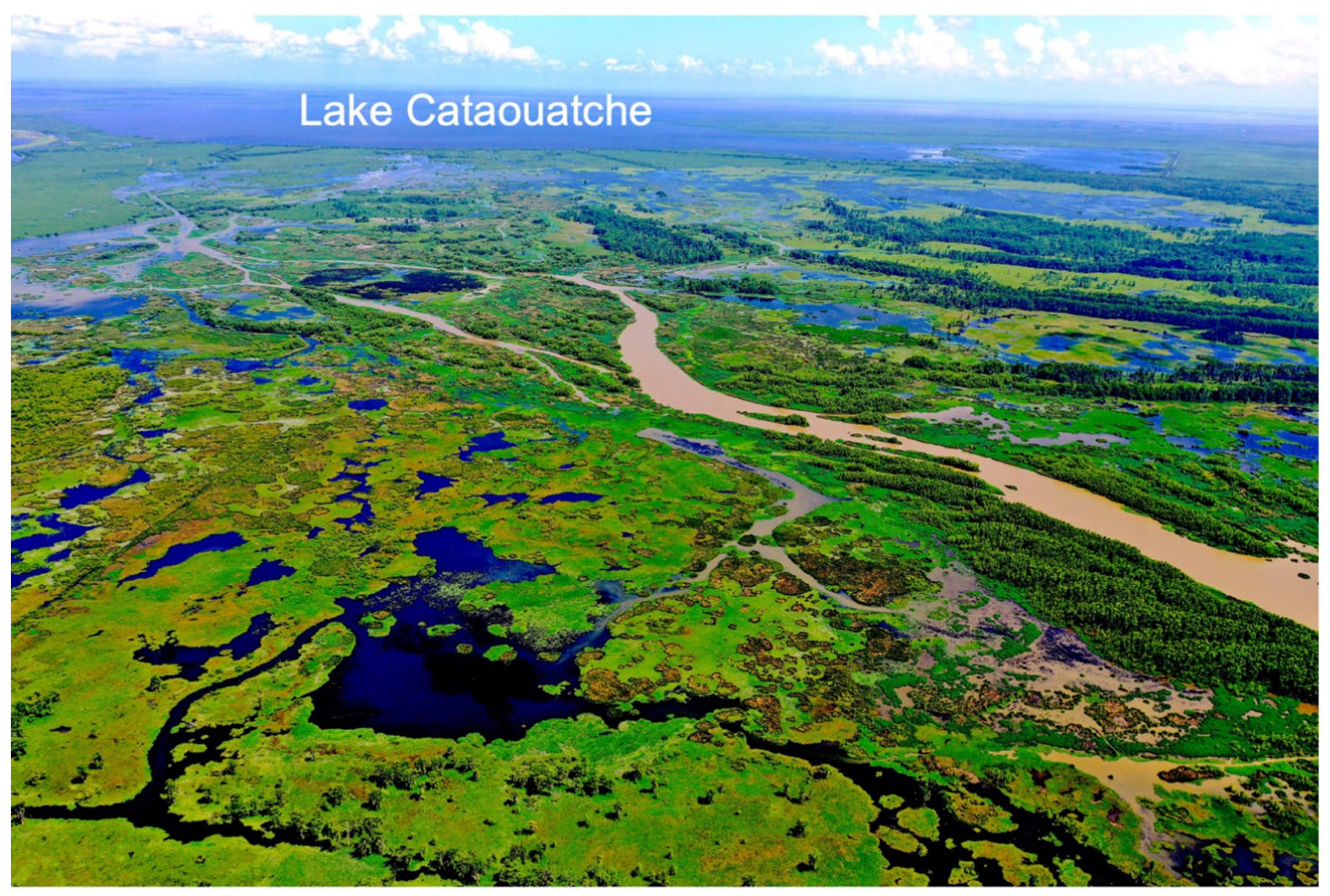

Fig. 2 An aerial image of the ponding area with turbid river water entering from the lower right and then flowing towards southwards to exit into Lake Cataouatche at the top of the photo 
samples were collected from 1999 to 2016, but Lake Cataouche was sampled only from 2002 to 2007.

Briefly, we collected surface water in pre-rinsed Nalgene bottles, transported them in a cooler to the laboratory within $3 \mathrm{~h}$ where they were filtered upon arrival to determine the Chl $a$ concentration. The inorganic carbon, inorganic minerals, and the total carbon $(\mathrm{C})$, nitrogen $(\mathrm{N})$ and phosphorus $(\mathrm{P})$ concentrations were run on unfiltered samples. Portions were frozen for analysis of inorganic fractions identified below. Freezing samples may result in a potential $10 \%$ increase in the absolute concentration of phosphate (Chapman \& Mostert, 1990). Monthly Chl $a$ concentrations in Little Lake for 1974 to 1995 were collected by a related environmental monitoring program and are in Turner et al. (2021).

Water quality analysis

All water quality methods used are reported in Turner et al. (2019b), which employed standard laboratory practices for standards, blanks, and analytical replicates. Suspended sediment matter samples were filtered through pre-weighed grade $\mathrm{C}$ borosilicate glass fiber filters $(1.1 \mu \mathrm{m})$ that were pre-combusted at $550{ }^{\circ} \mathrm{C}$ for $1 \mathrm{~h}$. The post-filtration filters were dried at $60{ }^{\circ} \mathrm{C}$ for $24 \mathrm{~h}$ and re-weighed to determine the total suspended matter (TSS); then they were heated to $550{ }^{\circ} \mathrm{C}$ for $1.0 \mathrm{~h}$ and re-weighed again to determine the amount of inorganic and organic suspended matter.

Inorganic forms of $\mathrm{N}, \mathrm{P}$, and silicate (DSi) were determined in unfiltered water samples that were frozen until determination using either a Technicon Autoanalyzer II (USEPA Method 353.2 for ammonium and nitrate+ nitrite (DIN), USEPA Method 365.2 for phosphate (DIP), and Technicon Method 186-72 W/B for silicate) or a Lachat Quick-Chem 8000 Flow Injection Analyzer using the Lachat Methods approved by USEPA: Method 31-10706-1-B for ammonium, Method 31-107-04-1-C for nitrate + nitrite (herein 'nitrate'), Method 31-1-11501-1-H for inorganic phosphate (DIP), and Method 31-114-27-1-C for DSi.

We compared differences in the concentration of inorganics in water samples that were filtered or unfiltered using $0.45 \mu \mathrm{m}$ pore-size filters and found no significant differences between them. The Coefficient of Determination $\left(R^{2}\right)$ for nitrate + nitrite, ammonium, phosphate and silicate was $0.99,0.99,0.87$ and 0.97 , respectively, for 67, 67, 66, and 67 samples, respectively. The $R^{2}$ for the standard curve was $>0.98$ for all nutrient analyses.

The total $\mathrm{C}, \mathrm{N}$ and $\mathrm{P}$ determinations were done on unfiltered water samples that included inorganic and organic forms and the particulates. The concentration of Total Carbon (TC) was measured using a Shimadzu® TOC-5000A Analyzer. Total Organic Carbon (TOC) was measured by acidifying samples with $\mathrm{HCl}$ and then sparging before analysis to remove the inorganic Carbon (IC). Total nitrogen (TN) and total phosphorus (TP) concentrations were measured using a Technicon Autoanalyzer II or LaChat Quick-Chem after persulfate wet oxidation digestion (Raimbault et al., 1999).

Water for Chl a determinations was filtered through Grade F borosilicate glass fiber filters $(0.7 \mu \mathrm{m})$ and the filters put in $5 \mathrm{ml}$ of dimethyl sulfoxide-90\% acetone (40:60 by volume) for $2 \mathrm{~h}$ in the dark to extract the Chl $a$ (Lohrenz et al., 1999). The Chl $a$ concentration was estimated using a Turner Model 10 fluorometer calibrated with a chemical supply house standard.

\section{Fertilizer use}

The amount of nitrogen and phosphorus fertilizer used in agriculture for the three parishes surrounding the northern Barataria watershed (St. John, St. James and Lafourche) from 1945 to 2012 are from Alexander and Smith (1990), Gronberg and Spahr (2012), and Brakehill and Gronberg (2017). These parishes overlap watershed boundaries and are therefore estimates of fertilizer sales in a whole parish and do not precisely represent fertilizer use in only the Barataria watershed.

\section{Diversion discharge}

The discharge volume into the ponding area was measured in the conveyance channel (Station DCPBA03) and is reported at the Louisiana Department of Natural Resources web site (https://www. sonris.com/) and by the United State Geological web site (Station 295501090190400; https://waterdata. usgs.gov/usa/nwis/uv?295501090190400). 
Statistical analyses

We used Prism 9.0.0 software (C) 2020 (GraphPad Software, Inc., La Jolla, CA) for statistical analyses. The mean and the standard error of the mean $(\mu \pm 1$ SEM) was calculated for each year or month for four station groupings: into Lake Cataouatche, within Lake Cataouatche, in the two channels alongside Couba Island, and in Lake Salvador. The annual concentration of analytes in the conveyance channel and the three other station grouping were compared to each other for the six annual averages of overlapping annual averages. Log transformations of the data were made for graphing purposes.

The retention of analytes after leaving the ponding area was calculated as a proportion of the analyte entering in the outfall channel going into the ponding area and compared to that found in three station groupings representing Lake Cataouatche, the Couba Island passes, and Lake Salvador. An ordinary oneway ANOVA with Dunnett's multiple comparisons test with a single pooled variance was conducted to test for a significant difference between analyte concentrations in the outfall channel leading into the ponding area versus in water leaving the ponding area from the three downstream station groups. The retention rates of inorganics, $\mathrm{TN}$ and $\mathrm{TP}$ remaining in the outgoing water were graphed as a function of the discharge of water into the ponding area, the loading rate (mass per area) and the analyte concentration. We used a value for the dry inorganic soil density of $2.61 \mathrm{~g} \mathrm{~cm}^{-3}$ (Delaune et al., 1983) to convert the inorganic mineral matter entering the ponding area into an average vertical accumulation of mineral matter for the entire ponding area. The discharge for individual trips were averaged for each year and compared to the annual discharge for all days using a linear regression analysis. A simple linear regression between fertilizer use and Chl $a$ concentration was made that also tested if there were differences between significant slopes.

\section{Results}

Diverted water quantities

The amount of river water diverted into the ponding area in 2002 was 117 million $\mathrm{m}^{3}$ year ${ }^{-1}$ for when the diversion was open and averaged 0.24 million $\mathrm{m}^{3}$ da year $^{-1}$ for the sampling trips when it was opened that year (Fig. 3a). The discharge grew to a maximum of 11.6 million $\mathrm{m}^{3} \mathrm{da}_{\text {year }}{ }^{-1}$ in 2009 and had average discharge from 2003 to 2016 of 1,574 million $\mathrm{m}^{3}$ year $^{-1}$. The average daily discharge for all years was 1.016 times the daily average for the individual sampling trips that year. There was strong correlation $\left(R^{2}=0.85, P<0.01\right)$ between the daily discharge rate on trips that year and the annual discharge (Fig. 3b).

Analytic concentrations exiting the ponding area

All four sites near the ponding area were sampled on the same trip from 2002 to 2007 and the analyte concentrations can be compared to see if there were differences with water entering the ponding area. The concentrations of nitrate + nitrite and phosphate in the outfall channel declined when water reached Lake Cataouatche, the Couba Island passes, and near Lake Salvador. The concentration of ammonium did not decline in the Lake Cataoutche or in Lake Salvador but did decline in the Couba Island passes (Fig. 4c), whereas ammonium concentrations declined in Lake Cataoutche but not in Lake Salvador or Couba Island passes (Fig. 4d). Note that the concentration of ammonium is less than $5 \%$ of the $\mathrm{TN}$ and that there was a greater loss of nitrate
Fig. 3 The water discharge volume $\left(\mathrm{m}^{3}\right.$ year $\left.^{-1}\right)$ into the diversion conveyance channel. a Annual amounts. b The relationship between the average discharge on daily trips for that year $\left(\mathrm{m}^{3}\right.$ da year $^{-1}$ ) and the annual discharge for that year $\left(\mathrm{m}^{3}\right.$ year $^{-1}$ )
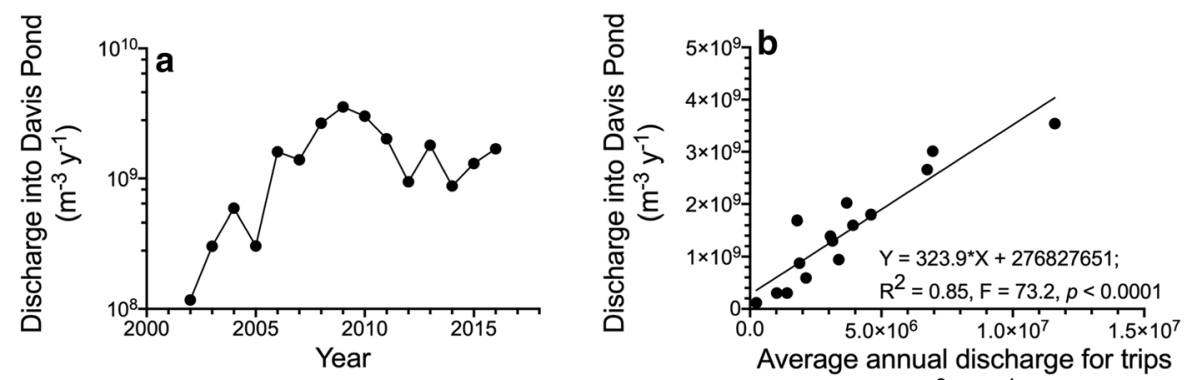

$\left(\mathrm{m}^{3}\right.$ day $\left.^{-1}\right)$ 
Fig. 4 Comparisons across values and locations of the average concentration of measured analytes by station groupings for data from 2002 to 2007 when equal sampling efforts were made. The mean \pm 1 SEM of the six annual values for each analyte at each station grouping is shown together with the results of an ANOVA testing for differences. a Inorganic sediments. b Total organic carbon. c Silicate. d Ammonium. e Nitrate + nitrite. $\mathbf{f}$ Total nitrogen. g Phosphate. h Total phosphorus. i Chlorophyll $a$
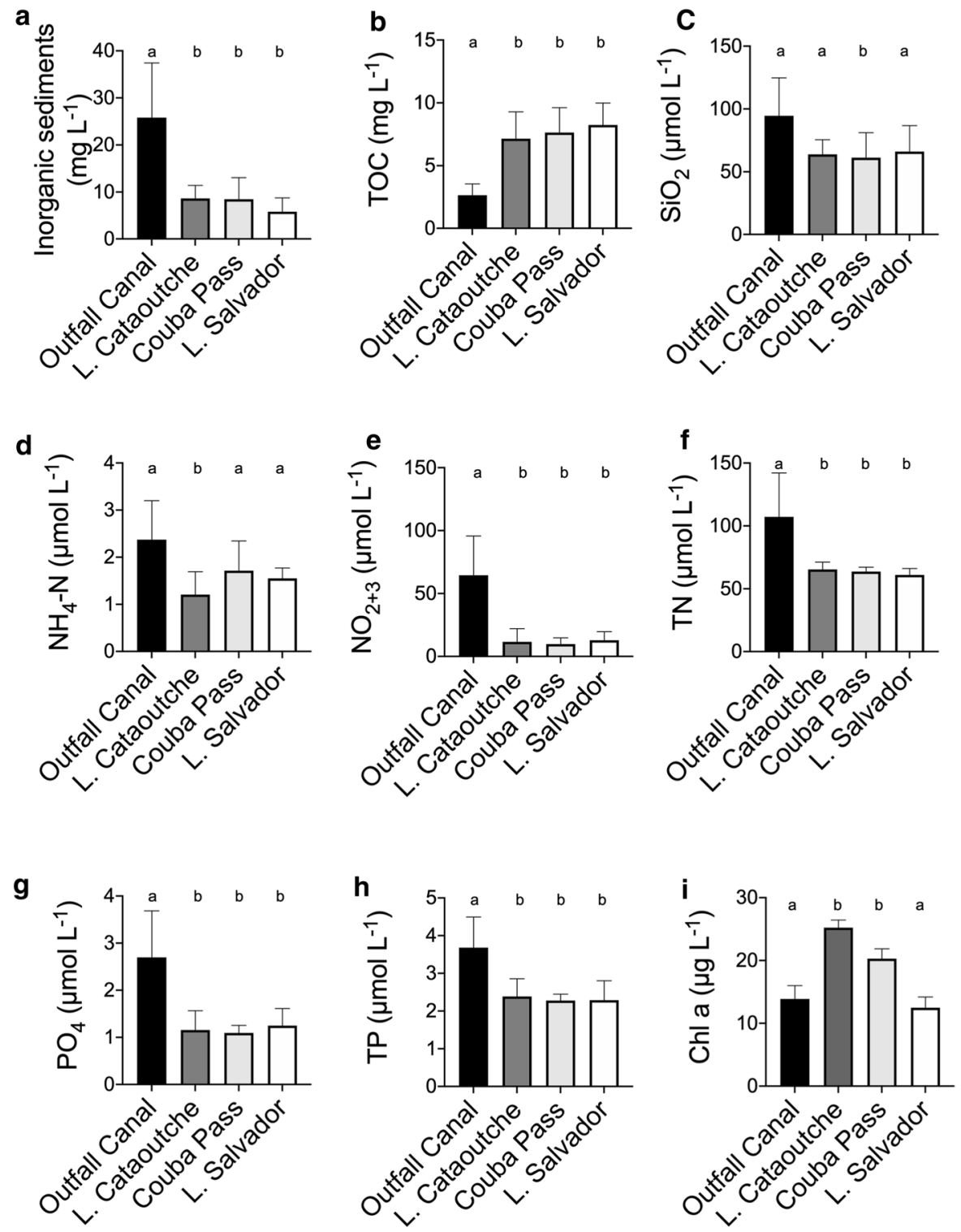

than TN (Fig. 4e, f). The concentrations of inorganic sediments, TOC, TN and TP (Fig. 4a, b, f, h) were lower in all three southerly stations compared to the concentration in the conveyance channel. The concentration of $\mathrm{TN}$ in the conveyance channel was nearly twice the nitrate concentration in the three downstream areas (Fig. 4f). Less than $10 \%$ nitrate passed through the ponding area (Fig. 4e). The Chl $a$ concentrations were highest in Lake Cataoutche and Couba Island passes, but not in Lake Salvador (Fig. 4i).
Retention of analytes

The retention of five major analytes in water reaching the Couba Island passes for the longer record from 2002 to 2016 is in Fig. 5. The retention rate varied from year to year but had consistent gains in TOC and Chl $a$, moderate losses in TN and TP, and much lower amounts departing the ponding area as inorganics. The average retention for these analytes in water leaving the ponding area for inorganics, $\mathrm{TN}$, and TP from 2003 to 2016 was $0.29 \pm 0.03,0.55 \pm 0.03$, 


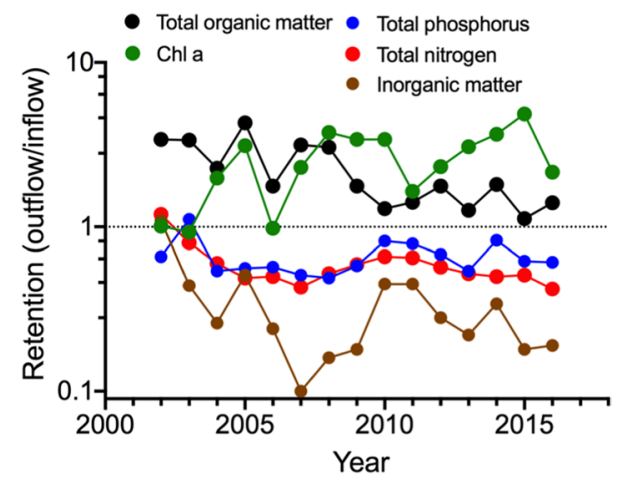

Fig. 5 The annual proportional retention (outflow/inflow) of total organic matter, $\mathrm{Chl} a$, Total phosphorous, total nitrogen and suspended inorganic matter in water flowing into and out of the Davis Pond ponding area at the stations on either side of Couba Island. The dotted line at $Y=1$ represents equal concentrations going into the ponding area and coming out

and $0.66 \pm 0.05 \%(\mu \pm \mathrm{SEM})$, respectively. In other words, about $71 \%, 45 \%$, and $34 \%$ of the inorganics, $\mathrm{TN}$, and TP in the conveyance channel, respectively, did not exit the ponding area as inorganics (Fig. 5); rather, significant amounts were converted to organic matter and Chl $a$ which increased (Fig. 5) as the inorganic forms of nitrogen and phosphorous decreased (Fig. 4).

The retention of inorganics, $\mathrm{TN}$, and $\mathrm{TP}$ are not clearly related to variations in discharge, loading per area, or analyte concentration (Fig. 6a-i). The exception was that the retention of $\mathrm{TN}$ declined with increases in TN concentration (Fig. 6h).

About half of the TP was trapped coincidentally with the inorganic matter (Fig. 7a), and the loss of phosphate was closely correlated with the amount of TP (Fig. 7b). This proportional loss result is consistent with the expectation that sediments contain phosphorus bound to clays. TN retention is also retained in proportion to inorganic material (Fig. 7c) but less conservatively relative to TP (Fig. 7d), probably because of denitrification rather than sedimentation. The outlier in Fig. 7a and c is the year of Hurricanes Katrina and Rita.

\section{Chlorophyll a in Little Lake}

The Chl $a$ concentration in Little Lake was linearly related to the use of $\mathrm{P}$ fertilizer in the watershed before and after the diversion was opened (Fig. 8a).
The two regression equations correlating Chl $a$ concentration with fertilizer had unequal slopes $(F=9.6$. $P<0.01)$ with a higher $\mathrm{Chl} a$ concentration per $\mathrm{P}$ fertilizer used after the diversion was opened. The diversion was not open before 2002 when P fertilizer use declined from 1978 to 1995 , whereas the $\mathrm{N}$ fertilizer increased as the Chl $a$ concentration declined (Fig. 8c, d). There was no relationship between $\mathrm{N}$ fertilizer use and Chl $a$ for before or after the diversion was opened (Fig. 8b). The $\mathrm{N}$ and $\mathrm{P}$ use, however, both declined after 2002 (Fig. 8). The outlier on Fig. 8a is for 2009 , which was the exceptionally high $\mathrm{P}$ loading rate that year. The lower trapping efficiency in 2009 resulted in a higher proportion of $\mathrm{P}$ leaving the Diversion ponding area, and the total $\mathrm{P}$ released into Lake Salvador peaked that year. These results indicate $\mathrm{P}$ limitation of $\mathrm{Chl} a$ concentration.

\section{Discussion}

Loading and removal rates

The $\mathrm{N}$ and $\mathrm{P}$ loading rates and removal rates are within the ranges stated in a review of the scientific literature by Land et al. (2016; Table 1). Their literature search of 5,853 unique records were screened for data quality to generate data on 203 wetlands located mostly in Europe and North America. The loading rate of $\mathrm{TN}\left(697 \pm 159 \mathrm{~kg} \mathrm{~N} \mathrm{ha}^{-1}\right.$ year $\left.^{-1}\right)$ and TP $\left(52.6 \pm 11.6 \mathrm{~kg} \mathrm{P} \mathrm{ha}^{-1}\right.$ year $\left.^{-1}\right)$ in the Davis Pond Diversion are within the range of loading rates for the Land et al. (2016) wetlands (Table 1), but almost one tenth of the average values of $5,050 \pm 5,790 \mathrm{~kg} \mathrm{~N} \mathrm{ha}^{-1}$ year $^{-1}$ and $630 \pm 730 \mathrm{~kg} \mathrm{P}$ $\mathrm{ha}^{-1}$ year $^{-1}$. The rates for the Davis Pond receiving basin are averaged for the entire area and would be highest closest to the point source.

Land et al. (2016) found that TN and TP removal rates over a $10^{9}$ size range varied with loading rate, air temperature, and wetland area and they noted that "wetlands with precipitation-driven hydraulic loading rates or hydrologic pulsing showed significantly lower TP removal efficiencies compared to wetlands with controlled hydrologic loading rates". The median removal rates that Land et al. (2016) found were $930 \mathrm{~kg} \mathrm{~N} \mathrm{ha}^{-1}$ year $^{-1}$ and $12 \mathrm{~kg} \mathrm{P} \mathrm{ha}^{-1}$ year $^{-1}$, amounting to a median retention rate in the outflow of $62 \%$ for TN and $50 \%$ for TP. The average removal rate 
Inorganics
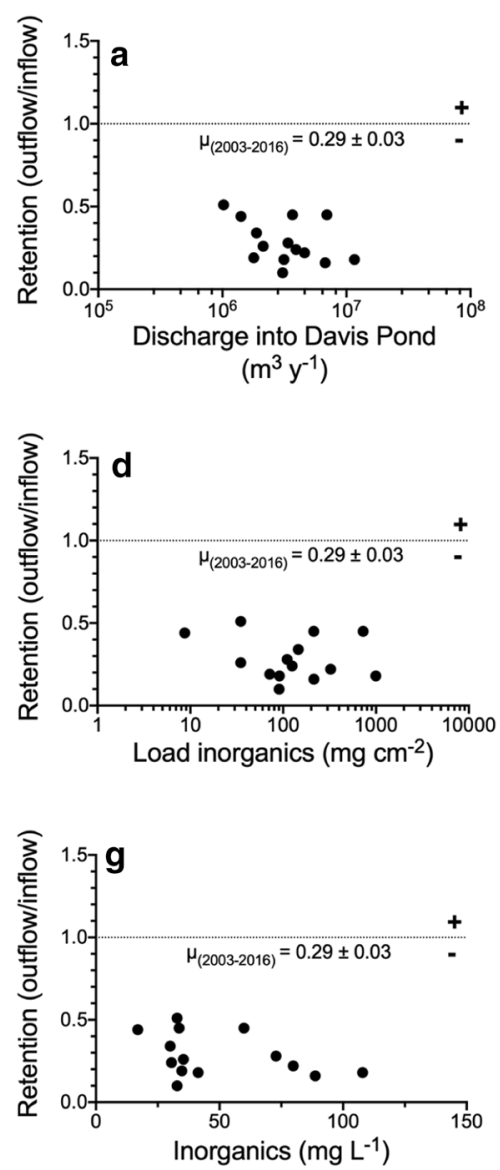

TN
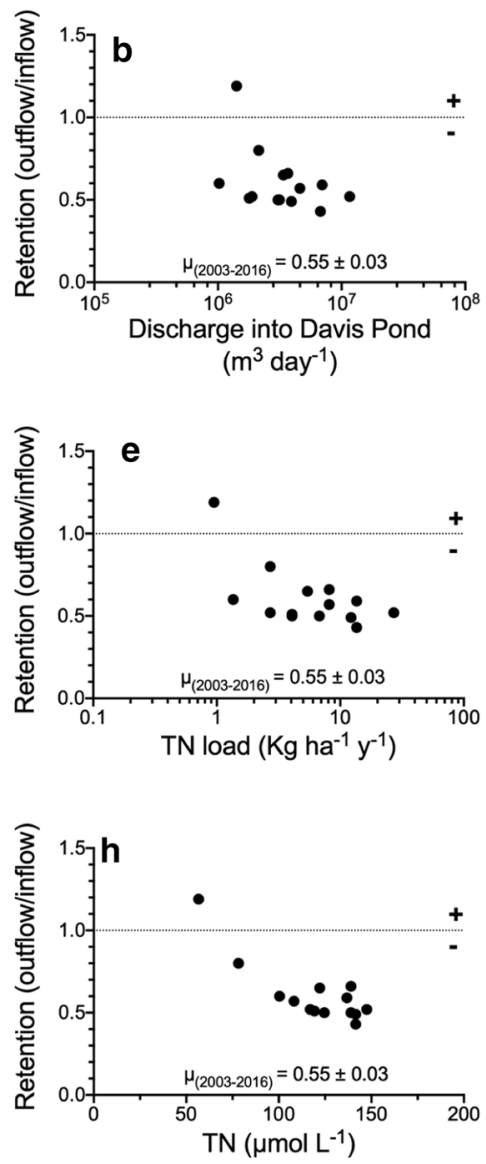

TP

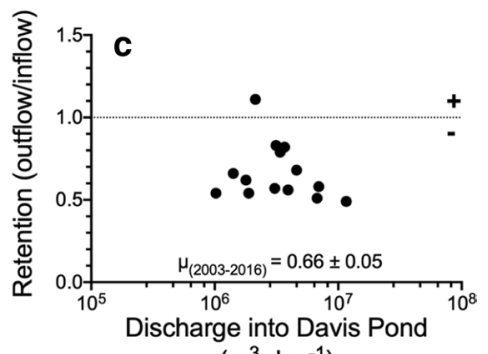

$\left(\mathrm{m}^{3}\right.$ day $\left.^{-1}\right)$
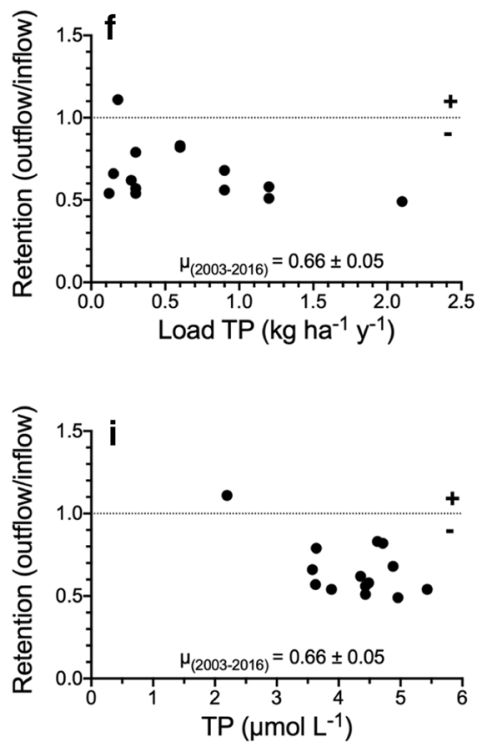

Fig. 6 The retention (outflow/inflow) of inorganic sediments, total nitrogen and total phosphorous vs. water discharge into the ponding area $(\mathbf{a}-\mathbf{c})$, the loading per area $(\mathbf{d}-\mathbf{f})$ and the

in their study was $1,840 \mathrm{~kg} \mathrm{~N}^{-1}$ year $^{-1}$ and $150 \mathrm{~kg}$ $\mathrm{P} \mathrm{ha}^{-1}$ year $^{-1}$, for an average $\mathrm{TN}$ and $\mathrm{TP}$ retention rate of $61 \%$ and $59 \%$, respectively, which is about the same as in for the whole Davis Pond Diversion flowpath. They make the point that before their study that the average removal rates suggested as sustainable (15 years before their article was published that) for nonpoint source treatment wetlands were 100 to $400 \mathrm{~kg} \mathrm{ha}^{-1}$ year $^{-1}$ for TN and 5 to $50 \mathrm{~kg} \mathrm{ha}^{-1}$ year $^{-1}$ for TP. The range of the median, average, and "earlier' removal rates were 10 to $1,830 \mathrm{~kg} \mathrm{~N}^{-1}$ year $^{-1}$ and 0.5 to $130 \mathrm{~kg} \mathrm{P} \mathrm{ha}^{-1} \mathrm{year}^{-1}$, whereas the removal rates in the Davis Pond Diversion were $316 \pm 82 \mathrm{~kg} \mathrm{~N} \mathrm{ha}{ }^{-1}$ year $^{-1}$ and $20.5 \pm 6.2 \mathrm{~kg} \mathrm{P}$ $\mathrm{ha}^{-1}$ year $^{-1}$ which puts the Davis Pond data in the middle range of removal rates described by Land water concentration $(\mathbf{g}-\mathbf{i})$, respectively. The dotted line at $Y=1$ represents an equal value going into and out of the ponding area

et al. (2016). The 30 year study in the Houghton Lake 100 ha wastewater treatment site (Kadlec, 2009a) had a TP loading rate of $18.7 \mathrm{~kg} \mathrm{P} \mathrm{ha}^{-1} \mathrm{year}^{-1}$, and a $17.6 \mathrm{~kg} \mathrm{P} \mathrm{ha}^{-1}$ year $^{-1}$ removal rate, corresponding to a $94 \%$ TP removal rate, which was a lower loading rate and higher percent removal rate than for the Davis Pond Diversion.

These declines in TN concentration after passing through the ponding area are in contrast to changes in TN concentrations in samples taken in channels from the Barataria watershed from Bayou des Allemands to the coast. The samples from channels downstream from the watershed show no significant declines that cannot be explained by dilution (Turner et al., 2019b). The difference in the reduction of TN concentration in water going through the diversion flow path and none 
Fig. 7 Linear regression plots illustrating the relationship between the annual retention of constituents into and out of the ponding area from 2003 to 2016 . a Inorganic vs. total phosphorous. $\mathbf{b}$ Total phosphorous and phosphate. $\mathbf{c}$ Inorganic vs. total nitrogen. d Total phosphorous and total nitrogen. The dotted line represents equal retentions going into the ponding area and coming out
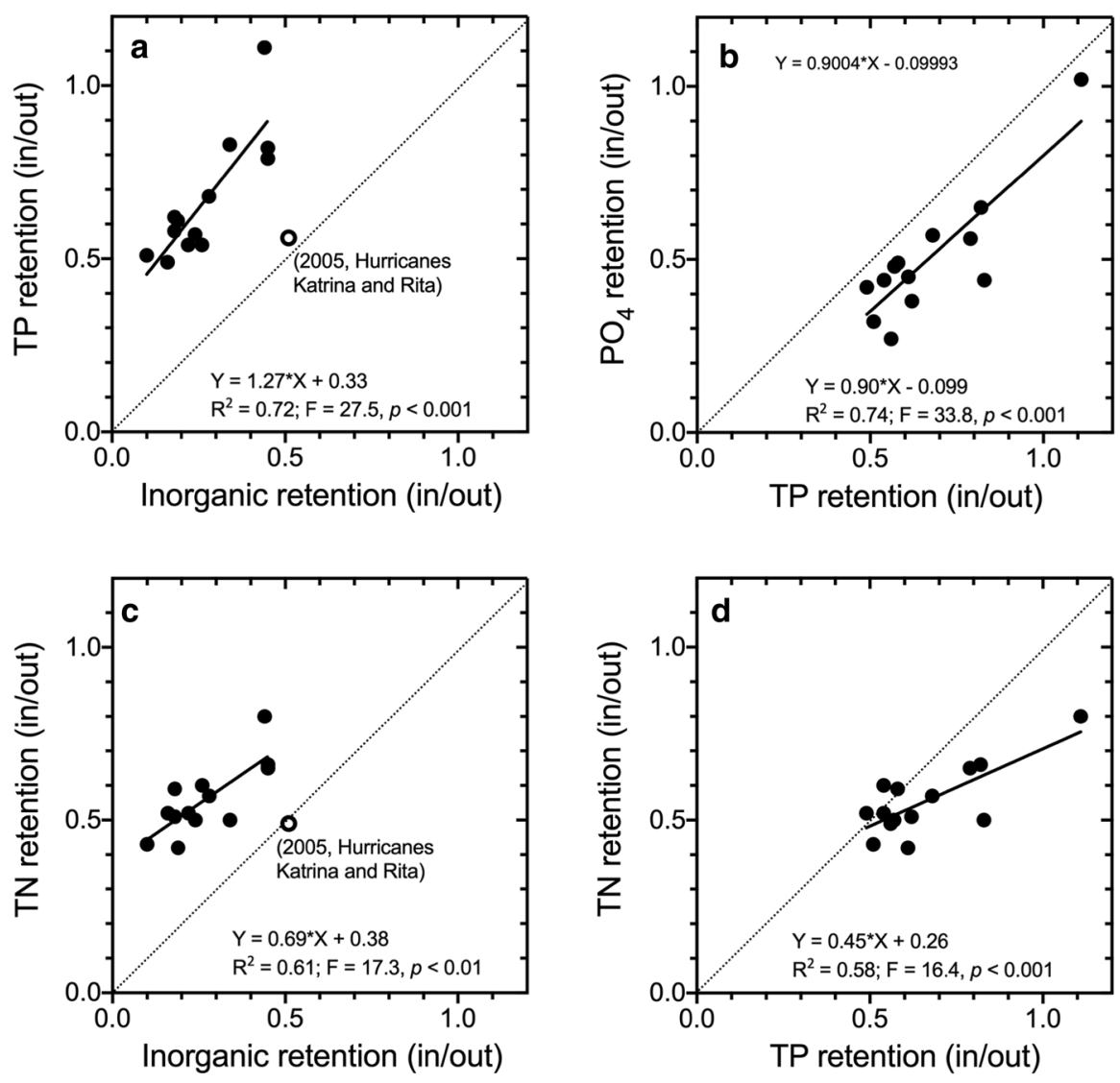

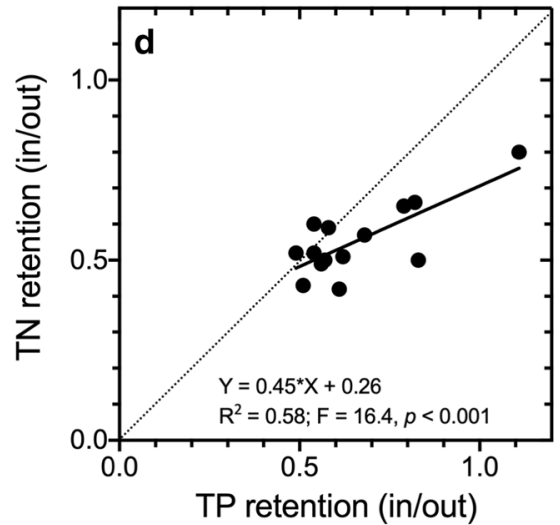

in channels may be because water remains mostly off the marsh as it travels toward the coast, whereas water goes overland in the constrained diversion channel.

Compromises to roots and soils from nutrient enrichment

The nutrient loading to wetland soils in the area of the diversion can have a subtle and significant effect on wetland soils and plants. The soil bulk density in the Davis Pond Diversion is $0.08 \pm 0.1 \mathrm{~g} \mathrm{~cm}^{3}$ (Delaune et al., 2013) which defines them as organic soils. Organic soils are negatively impacted as plants and soils are subjected to enhanced nutrient availability in tundra, salt marsh, brackish marsh and fresh marsh (Mack et al., 2004; Bragazza et al., 2006; Darby \& Turner, 2008; Turner, 2011; Deegan et al., 2012; Wigand et al., 2018; Turner et al., 2020; Herbert et al., 2020; Krause et al., 2020). The belowground biomass of roots and rhizomes decreases because plants put more resources into the above-ground biomass when access to nutrients is facilitated; root mass may increase in the upper few decimeters but decline at lower depths. Plant communities may change, therefore, because of the competitive advantages for nutrient foraging are altered. The first experiment demonstrating reduced root biomass accumulations of up to $50 \%$ after 3 years of nutrient additions was by Valiela et al. (1976) who also conducted root ingrowth experiments demonstrating a doubling of root growth in chambers filled with sand after several months of nutrient additions. Forty years later Graham \& Mendelsohn (2016) cleanly dissected why these two responses to nutrient additions yielded opposing results. They showed that ingrowth chambers represented an accommodation space for root growth not existing in field plots. An accommodation space might be created in the field when new sediments are added, after flooding stress opens up habitat space, or with plant death. To our knowledge, though, there are no examples that we know of that show stimulation of live belowground biomass in 
Fig. 8 The changing relationships of Chl $a$ concentrations $\left(\mu \mathrm{g} 1^{-1}\right)$ in Little Lake and the relative use of phosphorous fertilizer in the watershed for before and after the Davis Pond Diversion began operating. a $\mathrm{P}$ fertilizer use vs. Chl $a$ concentration each year for this study. A linear regression between variables is shown. b $\mathrm{N}$ fertilizer use vs. Chl $a$ concentration. c Annual P fertilizer use for each year. d Annual $\mathrm{N}$ fertilizer use for each year. e P loading $\left(\mathrm{kg} \mathrm{ha}^{-1}\right.$ year $^{-1}$ ) into the ponding area and outflow. Black circles denote concentrations before the diversion was opened. Open circles denote concentrations after it was opened
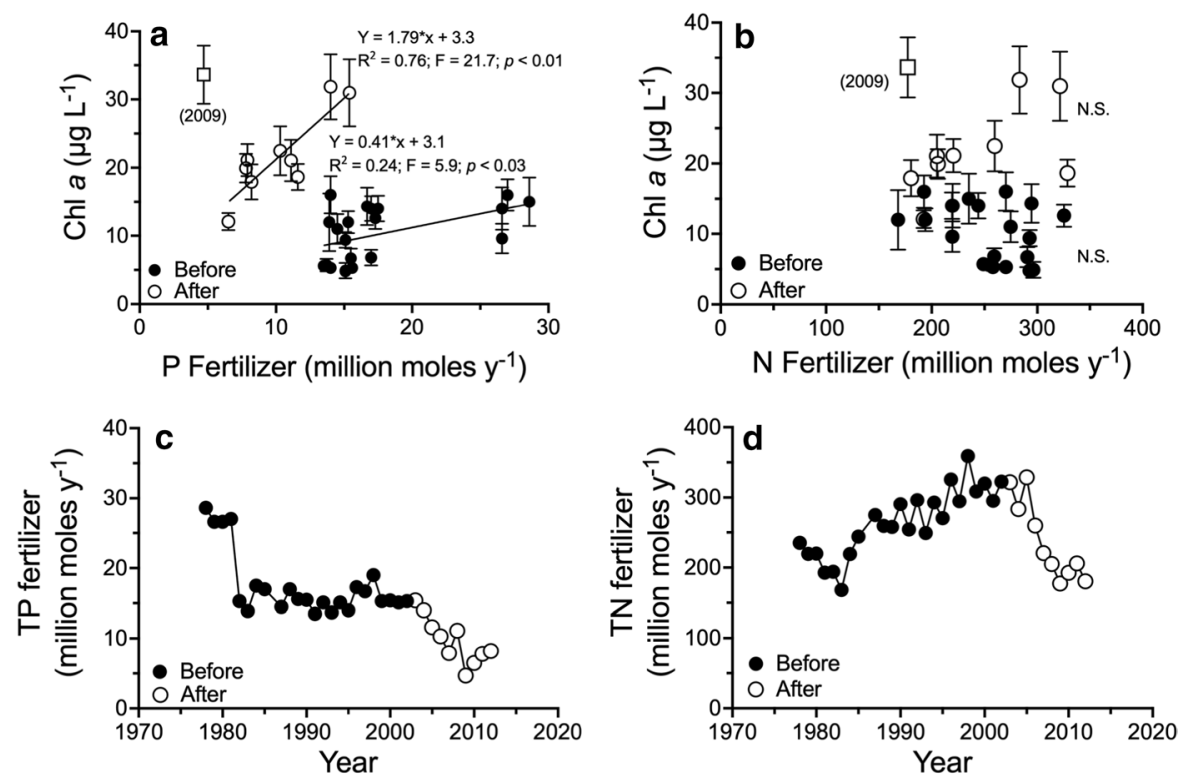

Table 1 Comparison with literature. Literature comparison of nutrient loading, removal, and retention rates for the river diversion at Davis Pond in the Barataria Basin of southern Louisiana

\begin{tabular}{|c|c|c|c|c|c|c|c|}
\hline & $\begin{array}{l}\text { Loading rate } \\
\mathrm{kg} \mathrm{ha}^{-1} \text { year }^{-1}\end{array}$ & $\begin{array}{l}\text { Loading rate } \\
\mathrm{kg} \mathrm{ha}^{-1} \text { year }^{-1}\end{array}$ & $\begin{array}{l}\text { Removal rate } \\
\mathrm{kg} \mathrm{ha}^{-1} \text { year }^{-1}\end{array}$ & $\begin{array}{l}\text { Percent } \\
\text { Removal rate }\end{array}$ & $\begin{array}{l}\text { Percent } \\
\text { Retention rate }\end{array}$ & $n$ & References \\
\hline & $\mathrm{TN}$ & Range & $\mathrm{TN}$ & & & & \\
\hline Median & 2,550 & $21-24,860$ & 930 & $38 \%$ & $62 \%$ & 112 & Land et al. (2016) \\
\hline Average & $5,050 \pm 5,790$ & $21-24,860$ & $1,810 \pm 2,510$ & $39 \% \pm 21 \%$ & $61 \%$ & 112 & \\
\hline 1990 estimates & - & - & 10 to 40 & - & - & - & \\
\hline Median & 32 & $0.3-3,730$ & 12 & $50 \%$ & $50 \%$ & 146 & Land et al. (2016) \\
\hline Average & $360 \pm 730$ & $0.3-3,730$ & $130 \pm 380$ & $41 \pm 52$ & $59 \%$ & 146 & \\
\hline \multirow[t]{2}{*}{1990 estimates } & - & - & 0.5 to 5 & - & - & - & \\
\hline & $\mathrm{TN}$ & & $\mathrm{TN}$ & $\mathrm{TN}$ & & & \\
\hline \multirow[t]{3}{*}{14 year average } & $697 \pm 159$ & - & $316 \pm 82$ & $39 \pm 19$ & $61 \%$ & & This study \\
\hline & $\mathrm{TP}$ & & $\mathrm{TP}$ & $\mathrm{TP}$ & & & \\
\hline & $52.6 \pm 11.6$ & - & $20.5 \pm 6.2$ & $34 \pm 17$ & $66 \%$ & & This study \\
\hline
\end{tabular}


intertidal marshes in existing soils, except where new accommodation space is provided for organic soils, as for example, when using ingrowth cores or sediment additions. The availability of sediments for deposition may compensate for less organic contributions, but it would be a premature, we think, to suggest that nutrient additions to organic soils will have the same effect as in mineral soils (Mozdzer et al., 2020). For example, the bulk density is about $0.24 \mathrm{~g} \mathrm{~cm}^{3}$ in the Graham \& Mendelsohn (2015) Sagittaria lancifolia L. dominated oligohaline marsh study. They showed that sediment trapping there compensated somewhat for the diminished amount of live root biomass in the upper $50 \mathrm{~cm}$ when fertilized.

A further consideration is that wetland soil strength can be reduced by adding either $\mathrm{N}$ or $\mathrm{P}$. The loading rates in the Davis Pond Diversion are comparable to those used in multi-year field experiments completed in floating freshwater marshes in the Salvador Wildlife Management Area that borders Davis Pond Diversion and in the anchored freshwater marshes located on the other side of the Mississippi River in the Joyce Wildlife Management Area near Hammond, LA (Turner et al., 2020). These experiments exposed wetlands to 3 different surficial additions of slow-release Osmocote ${ }^{\circledR}(450,1,360$ and 2,260 kg N ha $\mathrm{kg}^{-1}$, and 140, 430 and $710 \mathrm{~kg} \mathrm{P} \mathrm{ha}^{-1}$, respectively), and single doses of super phosphate $\left(\mathrm{Ca}\left(\mathrm{H}_{2} \mathrm{PO}_{4}\right)_{2} ; 520 \mathrm{~kg} \mathrm{P} \mathrm{ha}{ }^{-1}\right)$, or calcium nitrate $\left(\mathrm{Ca}\left(\mathrm{NO}_{2}\right)_{2} ; 250 \mathrm{~kg} \mathrm{~N} \mathrm{ha}^{-1}\right)$ to measure soil shear vane strength in the 0 to $100 \mathrm{~cm}$ soil depth. These loading rates from the field experiments are amounts applied to the experiment plots. The averages from the diversion flow path are for the entire area but applied at the northern end of the diversion flow path. The loading rates would be 10 times higher, for example, in the first $10 \%$ of the area nearest the entry point and lowest after it traversed the entire flow path. Turner et al. (2020) found that after six years that the average soil strength loss for the upper $100 \mathrm{~cm}$ in the anchored marshes ranged from 16 to $25 \%$ for all treatments, and that the weakest point in the $100 \mathrm{~cm}$ profile lost 15 to $23 \%$ of its soil strength. The equivalent loss in the floating marsh ranged from -1 to $18 \%$ for the entire profile, and 15 to $45 \%$ for the minimum loss at one of the $10 \mathrm{~cm}$ intervals. Interestingly, there was little change in soil strength in the top $30 \mathrm{~cm}$, whereas there were decreases below $30 \mathrm{~cm}$. Total biomass and soil strength are generally well-correlated among species in the upper $15 \mathrm{~cm}$ of the soil profile (Sasser et al., 2018). A loss of soil strength will result in a higher susceptibility to erosion.

The loss of soil strength below the weakest point in the soil depth is where the vegetative mats separated from the attached mat at nutrient-enhanced marsh at Hammond, LA (Turner et al., 2008). This is a recognized cause of enhanced nutrient availability to marshes-it occurred at sites where partially treated sewage was added to wetlands in Houghton Lake, MI and Hammond, LA (Kadlec \& Bevis, 2009; Turner et al., 2018) and is nicely illustrated in Fig. 3.3 in Kadlec and Wallace's encyclopedic review of constructed wetlands (2009; p. 1344) which summarized it this way: "Macrophyte roots have diminished in quantity and moved to higher horizons. As a result, the upper peat layers have greatly reduced strength since there are fewer live fibers. The dead roots have not consolidated, probably due to the new water regime, which provides little or no chance for drying. One result of these changes is greatly impeded foot travel". Multiple laboratory experiments measured the tensile strength of individual brackish marsh roots exposed to different nutrient loading and showed a 50\% decline in tensile strength (Hollis \& Turner, 2019a, 2021).

\section{Consequences for decomposition}

A second consequence of increased nutrient availability is the increased decomposition that develops where soils are oxygenated. Vascular terrestrial plant decomposition is almost always faster with nutrient enrichment at levels that are commonly found today in wetlands (Webster \& Benfield, 1986; Enriquéz et al., 1993; Bodker et al., 2015; Kominoski et al., 2015, Rosemond et al., 2015; Song et al., 2019). Various literature reviews conclude that plant communities undergoing increased nutrient availability tend to have faster growth rates, weakened cellular structure, expanded aerenchyma, allocate less biomass to roots, have higher nutrient concentrations in their biomass, and have leaky nutrient cycling, while carbon storage in the individual plant is higher (Aerts \& Chapin, 2000; Poorter \& Nagel, 2000). Darby and Turner (2008) demonstrated in Barataria Bay that the addition of $\mathrm{P}$, not $\mathrm{N}$, was the important nutrient involved in this reduction in live root biomass for salt marshes. Peat soils are comprised of a small amount of coarse 
material and a larger amount of fine-grained organic and mineral materials. It is sufficient that the coarse fibric root material which supports and holds together the fine-grained soil is weakened to destabilize the peat and bring about its collapse (Swarzenski et al., 2008).

\section{Sediment trapping compared to SLR}

The average amount of inorganic sediments left in the entire ponding area for all years (2002 to 2016) was $0.23 \pm 0.18 \mathrm{~g} \mathrm{~cm}^{-2}$ year $^{-1}$, equivalent to $0.62 \mathrm{~mm} \mathrm{year}^{-1}$ if the bulk density is $2.61 \mathrm{~g} \mathrm{~cm}^{-3}$ (Delaune et al., 1983). This rate is less than $10 \%$ of the $7.9 \pm 1.3 \mathrm{~mm}$ year $^{-1}$ accretion rate measured for three cores by Delaune et al. (2013) taken from the center of the ponding area, whose volumetric accumulation is attributed to organic accumulations, as elsewhere (Turner et al., 2001). The rise in sea level for the Gulf of Mexico measured at Key West, FL, was $5.6 \pm 0.86 \mathrm{~mm} \mathrm{year}^{-1}$ from 1997 to 2016 (Turner \& Rabalais, 2019). The inorganic sediment loading into the ponding area is grossly insufficient to balance the vertical accretion necessary to sustain these wetland systems exposed to these sea level rise rates. That means that organic matter accumulation, principally from belowground processes, is the dominant controlling factor contributing to vertical accretion. Whatever sediment leaves the ponding area will contribute insignificantly to vertical accretion in the downstream wetlands. Accretion rates may appear to be significant in a small portion of the ponding area, but not at the scale of the entire ponding area.

\section{Eutrophication}

The introduction of nutrients into an estuary are a well-documented and ubiquitous source of water quality problems causing fish kills, hypoxic zones, closed oyster beds, wetland loss, and reduced seagrass habitats (NRC, 2000; Cloern, 2001; Anderson et al., 2002; Howarth, 2006; Cloern \& Jassby, 2008; Deegan et al., 2012; Chorus et al., 2020, 2021). Bricker et al.'s (1999) survey of 138 estuaries in the US showed that $60 \%$ of them exhibited moderate to serious nutrient enrichment problems. A more recent national review of water quality in the United States (National Coastal Condition Report IV 2012; Tables 1-5) classified water quality as 'good, fair, and poor' with the cutoff for 'poor' being Chl $a$ concentrations above $20 \mu \mathrm{g} \mathrm{Chl} a \mathrm{1}^{-1}$. That upper limit has already been exceeded in Little Lake (Fig. 8) because of the added $\mathrm{P}$ from the Davis Pond Diversion, not the nitrogen cycling that is the focus of many studies (Delaune et al., 2005; Rivera-Monroy et al., 2010). The proposed diversions on the east and west bank of the Mississippi River (Mid-Breton Diversion and Mid-Barataria Diversion, respectively; Turner et al., 2019a) will deliver ten times more water volume into wetlands than at Davis Pond. It is not unreasonable, we think, to expect that $\mathrm{Chl} a$ concentrations will be even higher in the receiving basins if more diversions are built and that more wetland loss will occur, particularly after flooding vegetation (Brown et al., 2019). Eutrophication will surely be higher with larger diversions. The consequences for moving nutrients beyond the immediate area of sediment deposition at the outfall and into organic soils are obvious. For Davis Pond Diversion, the induced eutrophication occurs $40 \mathrm{~km}$ from the diversion outfall north of Couba Island. Why would the effects be different in the far field, beyond where sand deposition occurs near the outfall channel? There may be other nuances and unknowns to the effects, including to fish, plants and people, but assuming no additional impacts seems unrealistic.

\section{Conclusions}

Four outcomes from this analysis conflict with the rationale to open the Davis Pond Diversion in 2002:

1. The quantity of inorganics in the water diverted into the ponded area are grossly insufficient to make more than a minor addition to accretionary processes;

2. The removal rates of $\mathrm{TN}$ and $\mathrm{TP}$ are less than $40 \%$ for the entire ponding area;

3. The loading rates are at levels used in multiyear field studies that demonstrate lower belowground biomass;

4. TP is the limiting factor in this aquatic ecosystem, and so the effects of the diversion extend far outside of the diversion area to cause eutrophication in Little Lake (40 km away) and lower its water quality to the 'poor' category. 
Wetland restoration in the outflow area is not occurring; net wetland loss rates increased after the diversion opened. The introduced nutrients in the diverted water likely caused less, not more, belowground production, both inside and outside of the ponding area. The cumulative effect on soils is to reduce the elevation capital and carbon storage necessary for marsh sustainability in the ponding area and beyond. It is therefore unrealistic to expect wetland restoration in the ponding area.

Scientific understanding advances with an appreciation of ignorance-because everything is not known, and because new information may contradict expectations (Turner, 2009). Management decisions, therefore, are informed by both successes and failures. Here there seems to be mismatches with the facts that we know now and the management decision made years ago. The consequences of nutrient enhancements were largely unknown in 2002, but a simple analysis of the quantity of inorganic material in the diverted water would have shown that they could not make a significant volumetric contribution to compensate for sea level rise in the ponding area. The results of this analysis imply that the area of wetlands in the ponding area will continue to decline as a result of the diversion and that the estuary downstream will eutrophy and cause further wetland loss there too. Continuing to operate this diversion would be a failure to recognize the outcomes developing over the last 18 years. The diverted flow from the Mississippi River resulting from the proposed Mid-Breton Sound or Mid-Barataria Diversions will be ten times higher than from the Davis Pond Diversion. The results from the Davis Pond diversion may inform understanding of how the proposed two larger diversions, if built, will affect Louisiana's coastal wetlands beyond the immediate area of sand deposition.

Author contributions RET designed the research; JML established the sampling transect, JML, CM went on most sampling trips, JML, CM and EMS conducted most sample analysis, EMS archived data, RET wrote the first draft, and all authors contributed to subsequent drafts.

Funding This data collection and analysis was supported by multiple funding sources, including the NOAA Coastal Ocean Program MULTISTRESS Award No. NA16OP2670 to Louisiana State University, NSF Rapid Grant DEB-1044599, Northern Gulf Institute, and a Gulf of Mexico Research Initiative grant to the Coastal Waters Consortium. The Jefferson Parish Government, LA, Marnie Winters, Director at Jefferson Parish
Dept. of Environmental Affairs, provided support for pre-diversion sampling in Lake Cataouatche.

Data availability Data for this article are available at the website identified in the Acknowledgements.

Code availability Not applicable.

\section{Declarations}

Conflict of interest The authors declare no competing interest.

Ethics approval Not applicable.

Consent to participate Not applicable.

Consent for publication Not applicable.

Open Access This article is licensed under a Creative Commons Attribution 4.0 International License, which permits use, sharing, adaptation, distribution and reproduction in any medium or format, as long as you give appropriate credit to the original author(s) and the source, provide a link to the Creative Commons licence, and indicate if changes were made. The images or other third party material in this article are included in the article's Creative Commons licence, unless indicated otherwise in a credit line to the material. If material is not included in the article's Creative Commons licence and your intended use is not permitted by statutory regulation or exceeds the permitted use, you will need to obtain permission directly from the copyright holder. To view a copy of this licence, visit http://creativecommons.org/licenses/by/4.0/.

\section{References}

Aerts, R. \& F. S. Chapin III., 2000. The mineral nutrition of wild plants revisited: a re-evaluation of processes and patterns. Advances in Ecological Research 30: 1-67.

Alexander, R. B., \& R. A. Smith, 1990. County level estimates of nitrogen and phosphorus fertilizer use in the United States, 1945 to 1985: U.S. Geological Survey Open-File Report 90-130, 12 p. [available on internet at http://pubs. usgs.gov/of/ofr90130/].

Allison, M. A., C. R. Demas, B. A. Ebersole, B. A. Kleiss, C. D. Little, E. A. Meselhe, N. J. Powell, T. C. Pratt \& B. M. Vosburg, 2012. A water and sediment budget for the lower Mississippi-Atchafalaya River in flood years 20082010: implications for sediment discharge to the oceans and coastal restoration in Louisiana. Journal of Hydrology 432: 84-97.

Anderson, D. M., P. M. Glibert \& J. M. Burkholder, 2002. Harmful algal blooms and eutrophication: nutrient sources, composition and consequences. Estuaries 25: 704-726.

Ash, E. H. 2017. The draining of the Fens: projectors, popular politics, and state building in early modern England. 
Johns Hopkins Studies in the History of Technology. Baltimore, Maryland, USA.

Bodker, J. E., R. E. Turner, A. W. Tweel, C. Schulz \& C. Swarzenski, 2015. Nutrient-enhanced decomposition of belowground biomass of a freshwater wetland. Aquatic Botany 127: 44-52.

Bradley, P. M., B. Kjerfve \& J. T. Morris, 1990. Rediversion salinity change in the Cooper River, South Carolina: ecological implications. Estuaries 13: 373-379.

Bragazza, L., C. Freeman, T. Jones, H. Rydin, J. Limpens, N. Fenner, T. Ellis, M. Renat Gerdol, T Hájek. Hájek, P. Iacumin, L. Kutnar, T. Tahvanainen \& H. Toberman, 2006. Atmospheric nitrogen deposition promotes carbon loss from peat bogs. Proceedings of the National Academy of Sciences (USA) 103: 19386-19389.

Brakebill, J. W., \& J. M. Gronberg, 2017. County-level estimates of nitrogen and phosphorus from commercial fertilizer for the conterminous United States, 1987-2012: U.S. Geological Survey data release. https://doi.org/10.5066/ F7H41PKX

Bricker, S. B., C. G. Clement, D. E. Pirhalla, S. P. Orlando \& D. R. G. Farrow, 1999. National estuarine eutrophication assessment: effects of nutrient enrichment in the Nation's estuaries. NOAA, National Ocean Service, Special Projects Office, and the National Centers for Coastal Ocean Science, Silver Spring, MD.

Brown, M. 2006. When the $\$ 120$ million Davis Pond Diversion project opened in 2003, many supporters hailed it as a way to replenish the Louisiana marshlands. Times Picayune West Bureau, February 22, 2006.

Brown, G. L., J. N. McAlpin, N. Kimberly, K. C. Pevey, P. V. Luong, C. R. Price \& B. A. Kleiss, 2019. Mississippi River hydrodynamic and delta management study: delta management modeling. U.S. Army Engineer Research and Development Center (ERDC), Vicksburg, MS, Report ERDC/CHLTR-19-2. [available on inernet at http://acwc. sdp.sirsi.net/client/default]

Cencini, C., 1998. Physical processes and human activities in the evolution of the Po Delta, Italy. Journal of Coastal Research 14: 774-793.

Chapman, P. \& S. A. Mostert, 1990. Does freezing of nutrient samples cause analytical errors? South African Journal of Marine Science 9: 239-247.

Chorus, I. \& E. Spijkerman, 2021. What Colin Reynolds could tell us about nutrient limitation, $\mathrm{N}: \mathrm{P}$ ratios and eutrophication control. Hydrobiologia 848: 95-111.

Chorus, I., A. Köhler, C. Beulker, J. Fastner, K. van de Weyer, T. Hegewald \& M. Hupfer, 2020. Decades needed for ecosystem components to respond to a sharp and drastic phosphorus load reduction. Hydrobiologia 847: 4621-4651.

Cloern, J. E., 2001. Our evolving conceptual model of the coastal eutrophication problem. Marine Ecology Progress Series 210: 223-253.

Couvillion, B. R., H. Beck, D. Schoolmaster, \& M. Fischer, 2017. Land area change in coastal Louisiana (1932 to 2016) Pamphlet to accompany U.S. Geological Survey Scientific Investigations Map 3381

CPRA, 2020. BA-0001-Davis-Pond-Freshwater-Diversion-Fact-Sheet. Downloaded 31 Dec. 2020. http:// coastal. la.gov/wp-content/uploads/2020/03/
BA-0001-Davis-Pond-Freshwater-Diversion-Fact-Sheet. pdf. https://doi.org/10.1007/s10750-019-3918-7

Cloern, J. E. \& A. D. Jassby, 2008. Complex seasonal patterns of primary producers at the land-sea interface. Ecology Letters 11: 1294-1303.

Craft, C. V., E. D. Seneca \& S. W. Broome, 1993. Vertical accretion in microtidal regularly and irregularly flooded estuarine marshes. Estuarine, Coastal and Shelf Science 27: 371-386.

Darby, F. A. \& R. E. Turner, 2008a. Effects of eutrophication on salt marsh roots, rhizomes, and soils. Marine Ecology Progress Series 363: 63-70.

Darby, F. A. \& R. E. Turner, 2008b. Below- and aboveground biomass of Spartina alterniflora: response to nutrient addition in a Louisiana salt marsh. Estuaries and Coasts 31: $326-334$.

Das, A. 2010. Modeling the impacts of pulsed riverine inflows on hydrodynamics and water quality in the Barataria Bay estuary. Ph.D. Dissertation, Louisiana State University, Baton Rouge.

Deegan, L. A., D. S. Johnson, R. S. Warren, B. J. Peterson, J. W. Fleeger, S. Fagherazzi \& W. M. Wollheim, 2012. Coastal eutrophication as a driver of salt marsh loss. Nature 490: 388-392.

DeLaune, R. D., R. H. Baumann \& J. D. Gosselink, 1983. Relationships among vertical accretion, coastal submergence, and erosion in a Louisiana Gulf coast marsh. Journal of Sedimentary Petrology 53: 147-157.

DeLaune, R. D., A. Jugsujinda, J. L. West, C. B. Johnson \& M. Kongchum, 2005. A screening of the capacity of Louisiana freshwater wetlands to process nitrate in diverted Mississippi River water. Ecolological Engineering 25: 315-321.

Delaune, R. D., M. Kongchum, J. R. White \& A. Jugsujinda, 2013. Freshwater diversions as an ecosystem management tool for maintaining soil organic matter accretion in coastal marshes. Catena 107: 139-144.

Enríquez, S., C. M. Duarte \& K. Sand-Jensen, 1993. Patterns in decomposition rates among photosynthetic organisms: the importance of detritus $\mathrm{C}: \mathrm{N}$ : P content. Oecologia 94: 457-471.

Graham, S. A. \& I. A. Mendelssohn, 2015. Coastal wetland stability maintained through counterbalancing accretionary responses to chronic nutrient enrichment. Ecology 95: 3271-3283.

Graham, S. A. \& I. A. Mendelssohn, 2016. Contrasting effects of nutrient enrichment on below-ground biomass in coastal wetlands. Journal of Ecology 104: 249-260.

Gronberg, J. M. \& N. E. Spahr, 2012. County-level estimates of nitrogen and phosphorus from commercial fertilizer for the Conterminous United States, 1987-2006: U.S. Geological Survey Scientific Investigations Report 2012-5207, 20 p. https://pubs.usgs.gov/sir/2012/5207/

Gunderson, L. \& S. S. Light, 2006. Adaptive management and adaptive governance in the Everglades ecosystem. Policy Science 39: 323-334.

Herbert, E. R. \& J. P. Schubauer-Berigan, 2020. Effects of $10 \mathrm{yr}$ of nitrogen and phosphorus fertilization on carbon and nutrient cycling in a tidal freshwater marsh. Limnology and Oceanography 65: 1669-1687. 
Hollis, L. O. \& R. E. Turner, 2019a. The tensile root strength of Spartina patens varies with soil texture and atrazine concentration. Estuaries and Coasts 42: 1430-1439.

Hollis, L. O. \& R. E. Turner, 2019b. The tensile root strength of Spartina patens: response to atrazine exposure and nutrient addition. Wetlands 39(4): 759-775.

Hollis, L. O. \& R. E. Turner, 2021. The tensile root strength of Spartina patens declines with exposure to multiple stressors. Wetlands Ecology and Management 29: 143-153.

Howarth, R. W. \& R. Marino, 2006. Nitrogen as the limiting nutrient for eutrophication in coastal marine ecosystems: evolving views over three decades. Limnology and Oceanography 51: 364-376.

Kadlec, R. H., 2009. Wastewater treatment at the Houghton Lake wetland: soils and sediments. Ecological Engineering 35: 1333-1348.

Kadlec, R. \& F. Bevis, 2009. Wastewater treatment at the Houghton Lake wetland: vegetation response. Ecological Engineering 35: 1312-1332.

Kadlec, R. H. \& S. Wallace, 2009. Treatment Wetlands, CRC Press, Boca Raton:

Kesel, R. H., 1989. The role of the Mississippi River in wetland loss in Southeastern Louisiana, U.S.A. Environmental Geology and Water Science 13: 183-193.

Kominoski, J. S., A. D. Rosemond, J. P. Benstead, V. Gulis, J. C. Maerz \& D. W. P. Manning, 2015. Low-to-moderate nitrogen and phosphorus concentrations accelerate microbially driven litter breakdown rates. Ecological Applications 225: 856-865.

Krause, J. R., E. B. Watson, C. Wigand \& N. Maher, 2020. Are tidal salt marshes exposed to nutrient pollution more vulnerable to sea level rise? Wetlands 40: 1539-1548.

Land, M., W. Granéli, A. Grimvall, C. C. Hoffmann, W. J. Mitsch, K. S. Tonderski \& J. T. A. Verhoeven, 2016. How effective are created and restored freshwater wetlands for nitrogen and phosphorus removal? Summary of Systematic Review SR2. EviEM, Stockholm

Lohrenz, S. E., G. L. Fahnenstiel, D. G. Redalje, G. A. Lang, M. J. Dagg, T. E. Whitledge \& Q. F. Dortch, 1999. Nutrient, irradiance, and mixing as factors regulating primary production in coastal waters impacted by the Mississippi River plume. Continental Shelf Research 19: 1113-1141.

Mack, M. C., E. A. G. Schuur, M. S. Bret-Harte, G. R. Shaver \& F. S. Chapin, 2004. Ecosystem carbon storage in arctic tundra reduced by long-term nutrient fertilization. Nature 431: 440-443.

Megonigal, J. P., W. H. Conneer, S. Kroeger \& R. R. Sharitz, 1977. Aboveground production in southeastern floodplain forests: a test of the subsidy-stress hypothesis. Ecology 78: 370-384.

Mozdzer, T. J., E. B. Watson, W. H. Orem, C. Swarzenski \& R. E. Turner, 2020. Unraveling the Gordian Knot: eight testable hypotheses on the effects of nutrient enrichment in wetlands. Science of the Total Environment 743: 140420.

National Coastal Condition Report IV, 2012. United States Environmental Protection Agency Office of Research and Development/Office of Water, Washington, DC 20460, EPA-842-R-10-003; http://www.epa.gov/nccr
NRC (National Research Council), 2000. Clean coastal waters: understanding and reducing the effects of nutrient pollution, National Academy Press, Washington, DC:

Plitsch, E. M., 2018. 2017 Operations, Maintenance, and Monitoring Report for Davis Pond Freshwater Diversion (BA01), Coastal Protection and Restoration Authority of Louisiana, New Orleans

Poorter, H. \& O. Nagel, 2000. The role of biomass allocation in the growth response of plants to different levels of light, $\mathrm{CO}_{2}$, nutrients and water: a quantitative review. Australian Journal of Plant Physiology 27: 595-607.

Raimbault, P., W. Pouvesta, F. Diaz, N. Garcia \& R. Sempéré, 1999. Wet-oxidation and automated colorimetry for simultaneous determination of organic carbon, nitrogen \& phosphorus dissolved in seawater. Marine Chemistry 66: 166-169.

Rivera-Monroy, V. H., P. Lenaker, R. R. Twilley, R. DeLaune, C. Lindau, W. Nuttle, E. Habib, R. Fulweiler \& E. Castaneda-Moya, 2010. Denitrification in coastal Louisiana: a spatial assessment and research needs. Journal of Sea Research 63: 157-172.

Rivera-Monroy, V. H., B. Branoff, E. Meselhe, A. McCorquodale, Q. Dortch, G. D. Steyer, J. Visser, \& H. Wang, 2013. Landscape-level estimation of nitrogen removal in coastal Louisiana wetlands: potential sinks under different restoration scenarios. In Peyronnin, N. \& D. Reed (eds), Louisiana's 2012 Coastal Master Plan Technical Analysis. Journal of Coastal Research, Special Issue No. 67: 75-87.

Rosemond, A. D., J. P. Benstead, P. M. Bumpers, V. Gulis, J. S. Kominoski, D. W. P. Manning, K. Suberkropp \& J. B. Wallace, 2015. Experimental nutrient additions accelerate terrestrial carbon loss from stream ecosystems. Science 347: 1143-1145.

Sasser, C. E., E. Evers-Hebert, G. O. Holm Jr., B. Milan, J. B. Sasser, E. F. Peterson \& R. D. DeLaune, 2018. Relationships of marsh soil strength to belowground vegetation biomass in Louisiana coastal marshes. Wetlands 38: 401-409.

Schaefer, G. P., J. W. Day, D. Kandalepas, W. B. Wood, R. G. Hunter, R. R. Lane \& E. R. Hillmann, 2016. Decline of the Maurepas Swamp, Pontchartrain Basin, Louisiana, and approaches to restoration. Water 8: 101.

Song, J., S. Wan, S. Piao, A. K. Knapp, A. T. Classen, S. Vicca, P. Ciais, M. J. Hovenden, S. Leuzinger, C. Beier, P. Kardol, J. Xia, Q. Liu, J. Ru, Z. Zhou, Y. Luo, D. Guo, J. A. Langley, J. Zscheischler, J. S. Dukes, J. Tang, J. Chen, K. S. Hofmockel, L. M. Kueppers, L. Rustad, L. Liu, M. D. Smith, P. H. Templer, R. Q. Thomas, R. J. Norby, R. P. Phillips, S. Niu, S. Fatichi, Y. Wang, P. Shao, H. Han, D. Wang, L. Lei, J. Wang, X. Li, Q. Zhang, X. Li, F. Su, B. Liu, F. Yang, G. Ma, G. Li, Y. Liu, Y. Liu, Z. Yang, K. Zhang, Y. Miao, M. Hu, C. Yan, A. Zhang, M. Zhong, Y. Hui, Y. Li \& M. Zheng, 2019. A meta-analysis of 1,119 manipulative experiments on terrestrial carbon-cycling responses to global change. Nature Ecology and Evolution 3: $1309-1320$.

Swarzenski, C. M., 2003. Surface-water hydrology of the Gulf Intracoastal Waterway in South-Central Louisiana, 199699. U.S. Geological Survey Professional Paper 1672. Reston, VA. 
Swarzenski, C. M., T. W. Doyle, B. Fry \& T. G. Hargis, 2008. Biogeochemical response of organic-rich freshwater marshes in the Louisiana delta plain to chronic river water influx. Biogeochemistry 90: 49-63.

Swenson, E. M. \& R. E. Turner, 1998. Past, Present and Probable Future Salinity Variations in the Barataria Estuarine System. Coastal Ecology Institute, Louisiana State University, Baton Rouge, Louisiana. Prepared for the Office of Coastal Restoration and Management, Louisiana Department of Natural Resources (DNR Contract No. 2509-98-01). 446 pp. (with Appendices)

Swenson, E. M., J. E. Cable, B. Fry, D. Justic, A. Das, G. Snedden, \& C. Swarzenski, 2006. Estuarine flushing times influenced by freshwater diversions. In Singh, V. P. \& Y. J. Xu (eds), Coastal hydrology and processes. Proceedings of the 25th Anniversary Meeting and International Conference "Challenges in Coastal Hydrology and Water Quality". Water Resources Publications, LLC, Highland Ranch, Colorado, Chapter 33

Turner, R. E., 2001. Of manatees, mangroves, and the Mississippi River: is there an estuarine signature for the Gulf of Mexico? Estuaries 24: 139-150.

Turner, R. E., 2009. Doubt and the values of an ignorancebased world view for wetland restoration: coastal Louisiana. Estuaries and Coasts 32: 1054-1068.

Turner, R. E., 2011. Beneath the wetland canopy: loss of soil marsh strength with increasing nutrient load. Estuaries and Coasts 33: 1084-1093.

Turner, R. E., 2017. The mineral sediment loading of the modern Mississippi River Delta: what is the restoration baseline? Journal of Coastal Conservation 21(6): 867-872.

Turner, R. E., 2021. Declining bacteria, lead, and sulphate, and rising $\mathrm{pH}$ and oxygen in the lower Mississippi River. Ambio. https://doi.org/10.1007/s13280-020-01499-2.

Turner, R. E. \& J. E. Bodker, 2016. The effects of N, P and oil on the decomposition of Spartina alterniflora belowground biomass. Wetlands Ecology and Management 24(3): 373-380.

Turner, R. E. \& N. N. Rabalais, 2019. The Gulf of Mexico. In Shepard, C. (ed.), World seas: an environmental evaluation, Volume I: Europe Elsevier, The Americas and West Africa: 445-464.

Turner, R. E. \& E. M. Swenson, 2020. The life and death and consequences of canals and spoil banks in salt marshes. Wetlands 40: 1957-1965.

Turner, R. E., E. M. Swenson \& C. S. Milan, 2001. Organic and inorganic contributions to vertical accretion in salt marsh sediments. In Weinstein, M. \& D. A. Kreeger (eds), Concepts and controversies in tidal marsh ecology Kluwer Academic Publishing, Dordrecht: 583-595.
Turner, R. E., J. E. Bodker \& C. Schulz, 2018. The belowground intersection of nutrients and buoyancy in a freshwater marsh. Wetlands Ecology and Management 26(2): 151-159.

Turner, R. E., M. Layne, Y. Mo \& E. M. Swenson, 2019a. Net land gain or loss for two Mississippi River diversions: Caernarvon and Davis Pond. Restoration Ecology 27: 1231-1240.

Turner, R. E., E. M. Swenson, C. Milan \& J. M. Lee, 2019 b. Spatial variations in Chlorophyll $a, \mathrm{C}, \mathrm{N}$, and $\mathrm{P}$ in a Louisiana estuary from 1994 to 2016. Hydrobiologia 834(1): 131-144.

Turner, R. E., C. M. Swarzenski \& J. E. Bodker, 2020. Fresh marsh soil strength losses with small increases in $\mathrm{N}$ and $\mathrm{P}$ loading. Wetlands 40: 1189-1199.

Turner, R. E., C. S. Milan, J. M. Lee, \& E. M. Swenson. 2021. Phosphorus loading into a subtropical lake strongly influences nitrogen accumulation, nitrogen export and Chl $a$ concentration. Hydrobiologia 848: 4787-4800.

Valiela, I., J. M. Teal \& N. Y. Persson, 1976. Production dynamics of experimentally enriched saltmarsh vegetation: belowground biomass. Limnology and Oceanography 21: 245-252.

Wang, H., S. C. Piazza, L. A. Sharp, C. L. Stagg, B. R. Couvillion, G. D. Steyer \& T. E. McGinnis, 2017. Determining the spatial variability of wetland soil bulk density, organic matter, and the conversion factor between organic matter and organic carbon across coastal Louisiana, U.S.A. Journal of Coastal Research 33: 507-517.

Webster, J. R. \& E. F. Benfield, 1986. Vascular plant breakdown in freshwater ecosystems. Annual Review of Ecology and Systematics 17: 567-594.

White, E. D., F. Messina, L. Moss \& E. Meselhe, 2018. Salinity and marine mammal dynamics in Barataria Basin: historic patterns and modeled diversion scenarios. Water 10: 1015.

Wigand, C., D. E. B. Watson, R. Martin, D. S. Johnson, S. Warren, A. Hanson, E. Davey, R. Johnson \& L. Deegan, 2018. Discontinuities in soil strength contribute to destabilization of nutrient-enriched creeks. Ecosphere 9(8): e02329.

Publisher's Note Springer Nature remains neutral with regard to jurisdictional claims in published maps and institutional affiliations. 